\title{
PENINGKATAN KEMAMPUAN MENULIS PARAGRAF MELALUI PENERAPAN MODEL LOGIKA PROPOSISIONAL DAN LOGIKA PREDIKAT
}

\author{
Eti Hayati \\ Fakultas Keguruan dan Ilmu Pendidikan, Universitas Pamulang \\ etihayati.1403@gmail.com
}

\begin{abstract}
Abstrak
Penelitian ini dilakukan karena mahasiswa dalam setiap aktivitas perkuliahan selalu melakukan kegiatan menulis untuk menyelesaikan tugas-tugas perkuliahannya. Namun, berdasarkan observasi diketahui bahwa mahasiswa secara umum belum memperhatikan secara detail mengenai kohesi, koherensi dan pemanfaatkan jenis-jenis logika atau penalaran sebagai sarana berfikir ilmiah secara tepat dalam setiap kegiatan menulis. Tujuan penelitian ini adalah untuk meningkatkan kemampuan menulis paragraf melalui model logika proposisional dan logika predikat. Penelitian ini merupakan penelitian campuran dengan metode penelitian tindakan di Universitas Negeri Jakarta. Data penelitian ini diambil pada mahasiswa jurusan Biologi yang berjumlah 35 mahasiswa dan dianalisis secara kualitatif dan kuantitatif. Data dikumpulkan melalui pengamatan dan hasil tes mahasiswa. Hasil analisis dan interprestasi data, ditemukan adanya peningkatan terhadap kemampuan menulis paragraf mahasiswa. Secara kuantitatif, ditemukan bahwa kemampuan mahasiswa paragraf meningkat dari kegiatan siklus I hingga siklus III. Maka, dapat disimpulkan bahwa kemampuan menulis paragraf mahasiswa dapat ditingkatkan menggunakan model logika proposisional dan logika predikat. Bagi dosen sangat disarankan menggunakan model logika proposisional dan logika predikat sebagai salah satu model dalam meningkatkan kemampuan menulis paragraf. Selain itu, juga direkomendasikan kepada peneliti lain agar menggunakan penelitian ini sebagai bahan bagi penelitian selanjutnya.
\end{abstract}

Kata-kata kunci: kemampuan menulis paragraf, model logika proposisional, model logika predikat, penelitian tindakan

\footnotetext{
Jurnal Pendidikan Kewarganegaraan

Journal of Civics and Education Studies

The journal is published by Department of Civic Education

Faculty of Teacher Training and Education

Universitas Pamulang - Indonesia

Copyright $\odot 2017 \mid$ ISSN: 2302-0865
} 


\section{PENDAHULUAN}

Bahasa merupakan sarana berkomunikasi manusia. Komunikasi dapat dilakukan melalui sarana menulis. Menurut Kinayati (2007:97), Komunikasi menulis bisa diselaraskan sebagai alat komunikasi verbal yang digunakan dalm proses berpikir ilmiah di mana bahasa merupakan alat berpikir dan alat komunikasi untuk menyampaikan jalan pikiran tersebut kepada orang lain, baik pikiran yang berlandaskan logika induktif maupun deduktif.

J. B. Heaton menjelaskan bahwa kemampuan menulis merupakan hasil berpikir tertib dan kritis yang kala sulit untuk dijabarkan, memerlukan penguasaan tidak hanya dari gramatikal dan retoris tetapi juga dengan konseptual dan struktur (1989:135). Berdasarkan hal tersebut, peneliti mencoba merancang model logika proposisional dan logika predikat untuk meningkatkan kemampuan menulis, terutama dalam hal ini menulis paragraf karena berdasarkan observasi awal di kelas bahasa Indonesia, Mata Kuliah Umum (MKU), Universitas Negeri Jakarta, hal ini dilihat dari tes awal menulis paragraf, masih banyak mahasiswa semester pertama yang belum memperhatikan secara detail mengenai kohesi, koherensi dan pemanfaatan jenisjenis logika atau penalaran secara terstruktur.

Menurut Sabarti Akhadiah, dkk (1998:41), menulis merupakan proses bernalar, untuk menulis mengenai suatu topik peneliti harus berpikir, menghubung-hubungkan fakta, membandingkan dan sebagainya. Berpikir merupakan kegiatan mental. Kegiatan berpikir mungkin tidak terkendali, terjadi denga sendirinya, tanpa kesadaran, mislanya pada saat peneliti melamun. Kegiatan berpikir yang lebih tinggi dilakukan secara sadar, tersusun dalam urutan yang saling berhubungan, dan bertujuan untuk sampai kepada suatu kesimpulan. Jenis kegiatan berpikir yang terakhir inilah yang disebut kegiatan bernalar.

Soesinto (2003:3) menyatakan bahwa logika proposisional disusun dari suatu argumen (argument) yang logis. Argumen yang logis berisi proposisi-proposisi atomik (atomic propositions) yang tak mungkin lagi dipecahkan. Proposisiproposisi atomic tersebut dapat dirangkai atau dikombinasikan dengan berbagai perangkai (connective) menjadi proposisi majemuk (compound propositions), atau disebut juga ekspresi logika (logical expression).

Menurut Riemer, "A proposition is something which serves at the premise or conclision of an argument" - Proposisional adalah sesuatu yang berfungsi sebagai premis atas kesimpulan dari argumen. Sedangkan, logika predikat merupakan tingkatan kedua dari logika proposisional. Pernyataan-pernyataan atau argumen yang tidak bisa ditangani dengan logika proposisional akan ditangani oleh oleh logika predikat.

Kinayati (2007: 104), pemanfaatan logika dan penalaran dalam kegiatan menulis paragraf yang akan dilaksanakan dalam penelitian ini mengacu pada konsep bahwa penalaran merupakan suatu proses 
berpikir yang membuahkan pengetahuan. Berikutnya logika adalah studi tentang aturan-aturan mengenai penalaran yang tepat, serta bentuk dan pola pikiran yang masuk akan atau sah. Logika juga dipandang sebagai studi dan penerapan aturan-aturan penarikan kesimpulan pada argumen atau pada sistem pikiran. Merurut Jaszcolt, "Logic is a study of inference, of constructing a valid argument." Logika adalah belajar menyimpulkan, atas susunan uraian yang sah.

Model logika proposisional dan logika predikat dikonsep dan dirumuskan sehingga menjadi sebuah proses dalam menulis paragraf. Proses pertama mahasiswa menulis kalimat fakta, proses kedua mengembangkan kalimat fakta melalui penalaran sinonim, antonim, kata umum, dan kata khusus, proses ketiga mengembangkan kalimat fakta dengan penalaran definisi, klasifikasi, sebabakibat, contoh, analogi, dan generalisasi. Kemudian proses keempat, melalui penalaran deskripsi, eksposisi, persuasi, argumentasi, dan narasi.

Model logika proposisional dan logika predikat dirancang untuk meningkatkan kemampuan menulis paragraf, merujuk pada penelitian yang relevan. Penelitian yang dilakukan oleh Fathiaty (2012) dengan judul Peningkatan Kemampuan Menulis Argumentasi Melalui Strategi Metakognitif dan Berpikir Kritis (Penelitian Tindakan pada Mahasiswa di Jurusan Bahasa dan Sastra Indonesia Universitas Negeri Jakarta). Penelitian ini menyimpulkan pada latar belakang bahwa pengembangan menulis argumentasi dapat dilakukan dan ditingkatkan melalui strategi metakognitif karena mahasiswa harus merencanakan, kemudian memantau dan mengandalkan pikirannya, sedangkan berpikir kritis juga harus dilakukan mahasiswa dalam memahami masalah, menilai dengan mendasarkan analisis pada informasi dari berbagai sumber dan menarik kesimpulan dengan penalaran logis.

Penelitian yang berikutnya Hartati (2011) Universitas Muhammadiyah Jakarta, dalam penelitiannya menigkatkan kemampuan menulis eksposisi melalui model kooperatif teknik think-pair-share, dapat membuat mahasiswa aktif dalam proses pembelajaran khususnya pada keterampilan menulis eksposisi. Konsep ekposisi dijadikan rujukan yang relevan karena jenis eksposisi merupakan bagian dari salah satu konsep yang harus dikembangkan penalarannya dalam model logika proposisional dan predikat.

Penelitian yang relevan berikutnya, Marlando Wawolumaya (2011), Universitas Indonesia, dalam penelitiannya manifestasi logika pada bahasa dalam pemikiran Gottlob Frege: Sebuah telaah kritis. Konsep manifetasi logika dijadikan rujukan yang relevan karena dalam model yang dibuat merupakan sebuah turunan dari teori pemikiran plato dan aristoteles.

Dengan demikian, model logika proposisional dan logika predikat bertujuan untuk memudahkan mahasiswa dalam mengungkapkan gagasan fakta melalui pola logika secara terstruktur dengan langkah-langkah petunjuk penggunaan penalaran, sehingga 
kemampuan menulis paragraf mahasiswa diduga bisa mengalami peningkatan.

Penelitian ini digunakan untuk membedakan pernyataan fakta dan pernyataan pendapat, dimana pernyataan fakta dikembangkan melalui beberapa sistem penalaran, sehingga dari setiap paragraf akan terlihat cara-cara berpikir yang berbeda-beda, sehingga jika digabungkan paragraf-paragraf tersebut terlihat kohesi dan koherensinya. Dengan demikian, model logika proposisional dan logika predikat merupakan model cara berpikir dalam kegiatan menulis pargaraf yang mengutamakan analisi mahasiswa dalam menemukan konsep fakta melalui teks-teks bacaan dan objek-objek visual.

Langkah-langkah model logika ini memberi kemudahan mahasiswa untuk bekerja sendiri melalui jalur-jalur logika yang telah disediakan. Dengan demikian, model logika proposisional dan logika predikat dapat meningkatkan kemampuan menulis paragraf. Mahasiswa lebih kreatif dalam mengembangkan gagasangagasannya dan menentukan ide-ide hasil membaca teks, objek yang dilihatnya, maupun dalam mengaitkan isu-isi dan fenomena yang terjadi di lingkungan sekitar.

\section{METODE PENELITIAN}

Penelitian tindakan ini menggunakan model Ebbut. Model ini terdiri atas tiga tindakan, meliputi ide awal dikembangkan menjadi langkah tindakan pertama, kemudian tindakan pertama tersebut dimonitoring implementasi pengaruhnya terhadap subjek yang diteliti. Penelitian ini dilakukan pada mata kuliah bahasa Indonesia, di Unit Pelaksana Teknis Mata Kuliah Umum Universitas Negeri Jakarta (UPT MKU UNJ) dari bulan Oktober hingga Novemebr 2014. Data diperoleh dari mahasiswa Jurusan Biologi Fakultas FPMIPA yang sedang mengikuti mata kuliah umum Bahasa Indonesia dengan jumlah 35 orang melalui observasi.

Tes kemampuan menulis paragraf setiap siklus dilakukan sebanyak dua pertemuan. Setiap siklus mengikuti petunjuk dan sistematika menulis paragraf dengan model logika proposisional dan logika predikat dari lembaran instrumen. Selain itu, data diperoleh dari lembaran pengamatan dalam pengajaran dosen. Kemudian langkah-langkah menulis paragraf, diukur validitasnya dengan uji pakar terhadap Instrumen tersebut.

Langkah-langkah yang ada dalam proses menulis paragraf dengan model logika proposisional dan logika predikat harus tersistematis, mahasiswa melakukan proses pertama dengan urutan penalaran sinonim, antonim, kata umum, dan kata khusus. Proses kedua, dengan menggunakan penalaran definisi, klasifikasi, sebab-akibat, contoh, analogi, dan generalisasi. Proses ketiga dengan penalaran deskripsi, eksposisi, persuasi, argumentasi dan narasi. Berdasarkan uji pakar, diperoleh data bahwa dalam proses pertama urutan penalaran sinonim tidak harus ditulis pada kalimat pertama, tetapi dapat ditulis pada kalimat kedua, ketiga, keempat, ataupun kelima. Selanjutnya untuk proses kedua, urutan penalaran 
sebab-akibat ditempatkan pada urutan analogi begitupun sebaliknya.

Pengolahan data dianalisis menggunakan analisis data kualitatif dan analisis data kuantitatif, dari hasil tulisan mahasiswa yang berupa gabungan beberapa paragraf. Data kuantitatif diperoleh melalui tahapan-tahapan pengumpulan hasil catatan lapangan, hasil pengisian angket dari kolabolator dan uji pakar, klasifikasi data, deskripsi tulisan. Berikutnya analisis data kuantitatif digunakan untuk membandingkan kemampuan mahasiswa sebelum dan sesudah siklus tindakan berlangsung. Teknis analisis data yang digunakan adalah analisis uji $t$ untuk menguji keberartian perbedaan yang ada antara siklus 1 , siklus 2 , dan siklus 3 .

Pembahasan secara kualitatif, argumen-argumen fakta pada tulisan mahasiswa yaitu dengan memetakan argumen tersebut berdasarkan fungsi sintaksis, kemudian setelah itu dikelompokkan berdasarkan fungsi semantiknya. Adapun fungsi sintaksis memetakan konsep logika proposisional berdasarkan kategori fungsi sintaksis pada tulisan pola 1 dengan memetakan pernyataan fakta berdasarkan kata sinonim, antonim, kata umum, dan kata khusus. Sedangkan fungsi sintaksis pada tulisan pola 2 dengan memetakan pernyataan fakta berdasarkan konsep definisi, klasifikasi, sebab-akibat, contoh, analogi dan genarlisasi.

Fungsi sintaksis pada tulisan pola 3 dengan memetakan pernyataan fakta berdasarkan konsep deskripsi, eksposisi, persuasi, argumentasi, dan narasi.
Sedangkan fungsi semantik memetakan konsep logika predikat dengan menjumlahkan argumen fakta yang dihasilkan dari pengembangan predikat.

\section{HASIL DAN PEMBAHASAN}

Keberhasilan tindakan ini terlihat dari adanya peningkatan hasil kemampuan menulis paragraf mahasiswa yang signifikan berdasarkan perubahan nilai dan argumen fakta yang beragam dalam setiap pernyataan yang diungkapkan melalui tulisan yang tersistematis melalui model logika proposisional dan logika predikat.

Hasil siklus 1 diperoleh nilai tertinggi 90 dan terendah 72 , siklus 2 diperoleh nilai tertinggi 93 dan terendah 67, berikutnya pada siklus 3 diperoleh nilai tertinggi 97 dan terendah 70. Upaya proses peningkatan pada siklus 1 , menulis paragraf antara kalimat 1 sampai kalimat 5, dalam 1 paragraf, mahasiswa harus memfokuskan pada predikat pada kalimat 1, kemudian mencari diksi lain dengan teknik menentukan sinonim, antonim, kata umum, dan kata khusus. Ide ini diharapkan dalam paragraf yang ditulis tidak terjadi gagasan yang berulang-ulang dalam satu paragraf tersebut.

Upaya berikutnya dengan memonitoring efek tindakan dengan memperbaiki ide pokok dari aspek struktur subjek, predikat, objek dan keterangan. Pneliti mencoba mencari strategi dengan cara kalimat pertama (ide pokok) disusun kembali secara beurutan susunannya mulai dari subjek, predikat, objek, kemudian keterangan, agar fokus 
predikatnya menjadi berubah yang diharapkan gagasan dikembangkan menjadi lebih mudah dalam menentukan sinonim, antonim, kata umum maupun kata khususnya.

Upaya pada siklus 2, pemahaman mahasiswa dari pengajaran manulis paragraf model logika proposisional dan logika predikat, berupa pemahaman penalaran definisi, klasifikasi, contoh, sebab-akibat, analogi, dan generalisasi. Kemudian upaya dilakukan pada siklus 3, mahasiswa diberi pengajaran untuk pemahaman mengenai konsep penalaran deskripsi, eksposisi, persuasi, argumentasi dan narasi. Sehingga diperoleh nilai
Rerata pretes 1 diperoleh nilai 66. Siklus 2 diperoleh nilai 96, siklus 3 diperoleh nilai 80,5 . Sedangkan Rerata postes siklus 1 diperoleh nilai 85 , siklus 2 diperoleh nilai 83, 5. Siklus 3 diperoleh nilai 84,5. Perbandingan tersebut kemudian analisis uji t bahwa $t_{\text {hit }}$ lebih besar daripada $t_{\text {tabel }}$ di dalam data tersebut dijumpai pada pretes-postes siklus $1(16,12>0,0065)$, pretes-postes siklus $2(16,12>0,0065)$, pretes-postes siklus $3(9,99>0,0065)$. Jadi, mengalami peningkatan yang signifikan.

Peningkatan yang signifikan dalam kemampuan menulis paragraf dapat dilihat pada gambar 1 berikut ini:

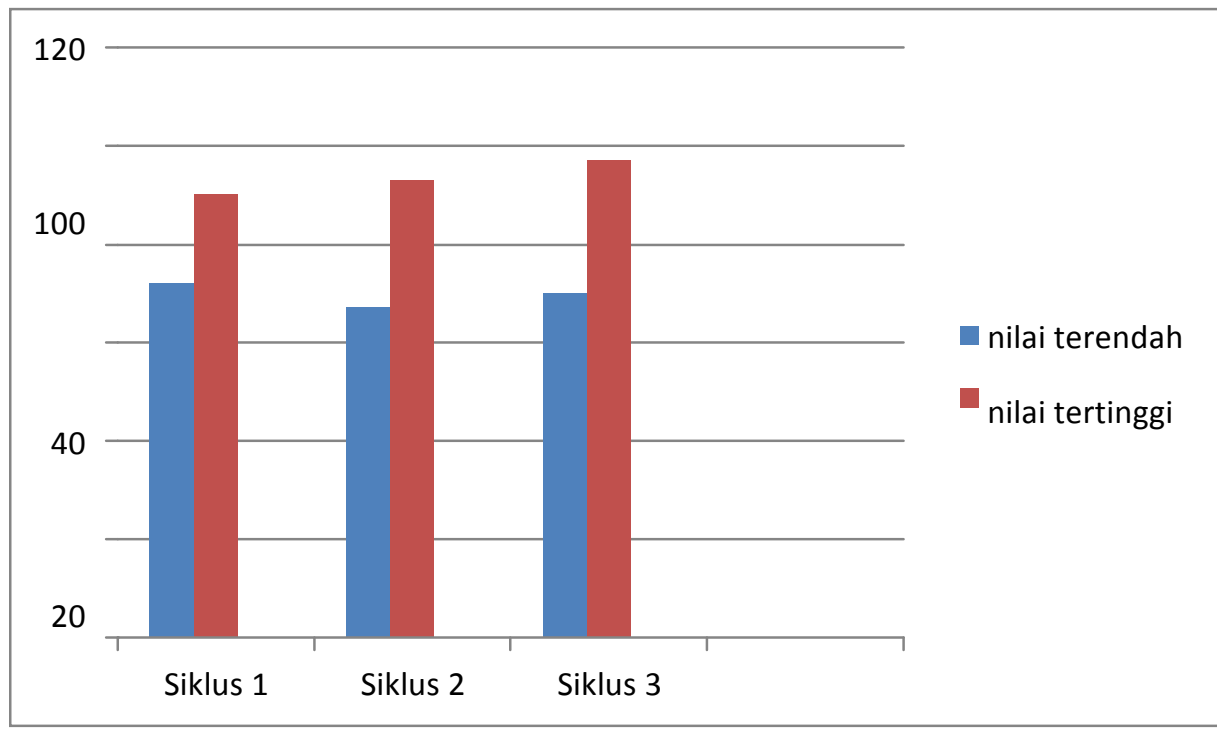

Gambar 1: Perbandingan nilai terendah dengan nilai tertinggi pada Siklus 1, 2 dan 3.

Perubahan-perubahan yang terjadi di masing-masing pertemuan pada setiap siklus telah memberikan gambaran yang berarti untuk bisa mengetahui peningkatan-peningkatan yang dialami oleh mahasiswa, baik dari segi kohesi dan koherensi dalam menulis paragraf. Tulisan paragraf mahasiswa setelah melewati 3 siklus yaitu enam pertemuan, akan dianalisis berdasarkan segi organisasi dan isi yang akan meruju pada semantik, sedangkan tata bahasa, kosa kata dan mekanik merujuk pada sintaksis. Maka, Gagasan yang berisi nalar fakta setelah diidentifikasi akan dianalisis berdasarkan makna semantik dan sintaksis. 
Maka, fungsi sintaksis dalam model logika proposisional dan logika predikat menjadi acuan untuk menganalisis struktur kalimat suatu gagasan fakta. Sedangkan fungsi semantiknya adalah untuk mempresentasikan makna dari sebuah gagasan fakta, sehingga bisa disimpulkan apakah gagasan tersebut telah sesuai dengan kohesi dan koherensi dalam model logika proposisional dan logika predikat.

Pembahasan hasil tulisan berupa data gagasan fakta dari segi tata bahasa, kosa kata, dan mekanik yang ada pada data tulisan 1, tulisan 2 dan tulisan 3. Dimana analisis sintaksis digunakan untuk gagasan proposisional secara struktur, sedangkan fungsi semantik adalah untuk mengetahui hubungan antara predikat dengan argumennya menghasilkan makna logika. Data yang dianalisis dalam Bab 4 ini diambil 15 sampel tulisan mahasiswa, dengan rincian siklus 1 , siklus 2 , dan siklus 3.

Dengan demikian, dapat disimpulkan dari pembahasan data sampel yang dianalisis, dari setiap kode melakukan tiga pola (tingkatan) aktivitas menulis paragraf melalui model logika proposisional dan logika predikat, dapat terlihat argumen fakta yang beragam dari setiap pola tingkatan tulisan satu, tulisan dua dengan tulisan tiga. Hal ini menunjukkan adanya peningkatan kemampuan mahasiswa dalam mengaitkan antara penalaran dengan pengetahuan yang dimiliki dari setiap mahasiswa tersebut.

\section{KESIMPULAN}

Berdasarkan hasil analisis penelitian ini, bisa ditarik kesimpulan bahwa penggunaan model logika proposisional dan logika predikat dapat meningkatkan kemampuan menulis paragraf mahasiswa Mata Kuliah Umum (MKU) bahasa Indonesia, jurusan biologi, Universitas Negeri Jakarta. Penggunaan model logika proposisional dan logika predikat dapat membuat mahasiswa mengembangkan argumen-argumennya pada pola penalaran yang terstruktur.

Mahasiswa lebih tersistematis untuk mengeluarkan gagasan- gagasannya lebih bervariasi temanya karena argumen fakta diungkapkan melalui pola terstruktur. Secara umum dengan model logika proposisional dan logika predikat dapat mengembangkan ide atau pemikirannya melalui aktivitas menulis.

Melalui proses model logika proposisional dan logika predikat, mahasiswa lebih terpetakan kemampuan kognitifnya dalam mengungkapkan pemahaman dan pengetahuannya. Sehingga langkah- langkah dalam model logika proposisional dan logika predikat efektif dalam meningkatkan kemampuan menulis paragraf mahasiswa.

\section{Saran}

Berdasarkan model logika proposisional dan logika predikat yang telah diterapkan pada mahasiswa jurusan Biologi angkatan 2014, penelitian ini memperlihatkan bahwa pelaksanaan pembelajaran dengan menggunakan model logika proposisional dan logika 
predikat pada mata kuliah bahasa Indonesia memberikan implikasi positif terhadap peningkatan kemampuan menulis paragraf mahasiswa. Berdasarkan temuan tersebut, pembelajaran menulis menghasilkan kegiatan yang terstruktur bagi mahasiswa.

Penggunaan model logika proporsional dan logika predikat ini memberikan sesuatu hal yang berbeda, mahasiswa yang awalnya hanya mengungkapkan gagasan secara bebas kini mereka sudah secara terstruktur dalam proses pembelajaran menulis. Indikasi ini dapat terlihat dari gagasan-gagasan yang beragam hasil tulisan mereka dalam setiap siklus.

Mahasiswa perlu melatih kemampuan bernalarnya, dengan mencari ide-ide baru melalui isu-isu yang berkembang di lingkungan sekitar, kemudian mengungkapkan gagasan-gagasan fakta tersebut melalui tulisan yang berlogika, yang terstruktur secara kohesi maupun koherensi. Mahasiswa perlu mengkonsep dalam pikirannya mengenai pola-pola bernalar, sehingga bisa diaplikasikan dalam bentuk tulisan.

Peneliti untuk penelitian tindakan dalam meningkatkan kemampuan menulis hendaknya lebih memperhatikan konsep penalaran yang akan diajarkan, yaitu konsep tulisan 1, tulisan 2, dan tulisan 3 yang ada pada model logika proposisional dan logika predikat. Komponen tersebut sangat penting untuk mendapatkan perhatian khusus bagaimana agar mahasiswa bisa meningkatkan kemampuan menulis paragraf dengan kohesi dan koherensi yang terstruktur.
Model logika proposisional dan logika predikat hendaknya dilatih cara mengungkapkan gagasan-gagasan melalui penalaran yang terstruktur dengan aktivitas menulis atau dengan aktivitas berbicara.

\section{REFERENSI}

Cummings, L. (2007). Pragmatik (Sebuah Perspektif Multidisipliner). Jakarta: Pustaka Pelajar Indonesia.

Djojosuroto, K. (2007). Filsafat Bahasa. Yogyakarta: Pustaka Book Publisher.

Heaton, J. B. (1989). Writing English Language Tests. London: Pearson Education.

Jaszczolt, K. M. (2002). Semantict And Pragmaticts. London: Pearson Education.

Khairah, M. \& Ridwan, S. (2014). Sintaksis (Memahami Satuan Kalimat Perspektif Fungsi). Jakarta: Bumi Aksara.

Riemer, N. (2010). Introducing Semantics. London: Cambridge University Press.

Sabarti, A., Arsjad, M. G., \& Ridwan, S. H. (1991). Pembinaan Kemampuan Menulis Bahasa Indonesia. Jakarta: Erlangga. 